Jurnal Syntax Imperatif: Jurnal Ilmu Sosial dan Pendidikan

p-ISSN: 2721-2491 e-ISSN: 2721-2246

Vol.1, No. 3, Juli 2020

\title{
Meningkatkan Hasil Pembelajaran Sejarah Indonesia dengan Metode Diskusi Terbimbing pada Siswa Kelas X TSM 1 di SMK Negeri 1 Gunung Jati Kabupaten Cirebon
}

\section{Yana}

SMK Negeri 1 Gunung Jati, Indonesia

E-mail: mpd.yana@gmail.com

\begin{abstract}
Abstrak
Sejarah merupakan bagian dari mata pelajaran ilmu pengetahuan sosial. Tujuan mempelajari sejarah adalah agar siswa dapat memahami apa yang terjadi di masa lampau, sehingga dapat menarik hikmah dari apa yang telah dipelajari dari peristiwa yang telah terjadi tersebut. Kenyataan di lapangan menunjukkan bahwa dalam proses pembelajaran sejarah siswa terlihat kurang antusias, daya kreativitasnya rendah, dan siswa bersikap acuh tak acuh. Dalam rangka meningkatkan hasil belajar sejarah kiranya diperlukan strategi pembelajaran yang tepat serta metode pembelajaran yang bervariasi. Salah satunya, yakni penggunaan metode diskusi yang dibimbing langsung oleh guru secara lebih mendalam. Melalui penggunaan metode diskusi terbimbing diharapkan para siswa kelas X TSM 1 mengetahui Materi Pokok Islamisasi dan Silang Budaya di Nusantara.
\end{abstract}

Kata Kunci: Sejarah; Metode Diskusi Terbimbing; Siswa Kelas X TSM 1

\section{Pendahuluan}

Sejarah adalah gambaran tentang peristiwa-peristiwa masa lampau yang dialami oleh manusia disusun secara ilmiah, meliputi urutan waktu, diberi tafsiran dan analisa kritis, sehingga mudah dimengerti dan dipahami.

Berdasarkan pengalaman penulis sebagai pengajar di kelas $\mathrm{X}$, hasil belajar IPS Sejarah Indonesia siswa kelas X TSM 1 sangat rendah. Nilai rata-rata hasil belajar dari hasil ulangan adalah 55. Kondisi di atas tentu sangat memprihatinkan. Untuk memperbaiki dan meningkatkan hail belajar siswa kelas X TSM 1 tersebut, banyak cara yang harus dilakukan. Untuk keperluan ini maka akan dicoba melalui penggunaan metode pembelajaran.

Adapun salah satu metode dalam pembelajaran tersebut adalah diskusi terbimbing. Hasil penelitian ini diharapkan dapat memberikan manfaat bagi guru tentang efektifitas diskusi terbimbing dalam proses belajar mengajar sejarah, sebagai bahan pertimbangan untuk meningkatkan kualitas proses belajar mengajar sehingga meningkatan hasil belajar di masa yang akan datang. Memberi informasi kepada masyarakat khususnya para pendidik akan kelebihan dan manfaat pengajaran Sejarah Indonesia dengan metode diskusi terbimbing (Slameto, 1991) 


\section{Metode Penelitian}

Penelitian ini merupakan penelitian tindakan kelas (classroom actionresearch). Prosedur penelitian tindakan kelas yang digunakan mengikuti model (Kemmis \& Taggart, 2002). Pendekatan penelitian ini digunakan karenapeneliti berupaya memperbaiki dan meningkatkan kualitas pembelajaran IPS Sejarah di sekolah.

Subyek adalah siswa kelas X, yang menunjukkan hasil belajarnya kurang yaitu 70, terbukti hasil ulangan harian dibawah rata-rata atau belum tuntas (angka ketuntasan 75). Berdasarkan kenyataan dan permasalahan di atas peneliti mencoba menggunakan metode diskusi terbimbing untuk Meningkatkan Hasil Pembelajaran Sejarah Indonesia dengan Metode Diskusi Terbimbing dalam Pokok Bahasan Islamisasi dan Silang Budaya di Nusantara Semester Ganjil Pada Siswa Kelas X TSM 1 Di SMK Negeri 1 Gunung Jati Kabupaten Cirebon

Dari penelitian ini terdapat dua variabel yaitu :

1. Variabel bebas (X). Variabel bebas dalam penelitian ini adalah penggunaan metode diskusi terbimbing dalam pelajaran Sejarah Indonesia $X$

2. Variabel terikat (Y). Variabel terikat dalam penelitian ini adalah hasil belajar Sejarah Indonesia setelah penggunaan media pengajaran diskusi terbimbing pada siswa kelas $\mathrm{X}$.

Metode pengumpulan data merupakan cara kerja untuk mendapatkan data dari obyek tertentu. Data yang didapatkan dalam penelitian dapat berupa data yang sifatnya kualitatif dan kuantitatif. Data adalah hasil pencatatan peneliti baik yang berupa fakta maupun angka (Suharsimi, 2006)

\section{Hasil dan Pembahasan}

\section{A. Hasil}

Dari hasil penelitian yang dilaksana ada beberapa hal yang perlu dibahas dalam penelitian ini. Nilai ketuntasan siswa dalam mata pelajaran Sejarah Indonesia adalah 75. Hasil penelitian yang diperoleh menunjukkan bahwa hasil dari nilai ketuntasan siswa ratarata sudah tercapai setelah menggunakan metode diskusi terbimbing.

Penelitian yang dilakukan dengan menggunakan tes awal didapat hasil rata-rata hanya 55. Hal ini menunjukkan bahwa siswa masih kurang dalam penguasan materi. Setelah diadakan pembelajaran yang menggunakan metode diskusi terbimbing dan diukur dengan menggunakan tes dapat dibuktikan dengan hasil penelitian yang dikategorikan cukup baik yaitu 73. Nilai seperti ini dapat dikategforikan memenuhi nilai ketuntasan dalam belajar Sejarah Indonesia.

Ada beberapa komponen yang dapat mendukung pencapaian tujuan pemahaman siswa terhadap bidang studi Sejarah yang terukur dalam hasil belajar Sejarah, yaitu penggunaan metode pembelajaran diskusi terbimbing. Metode diskusi terbimbing dapat 
berguna dan mampu mengantarkan siswa pada tujuan pembelajaran Sejarah Indonesia yang ingin dicapai berdasarkan kurikulum yang berlaku. Sesuai dengan kurikulum bahwa tujuan Pembelajaran Sejarah untuk memahami perkembangan bangsa Indonesia dengan memahami perkembangan masyarakat bangsa Indonesia. Pembelajaran secara teoritik menggunakan metode diskusi terbimbing menunjukkan bahwa hasil belajar siswa dapat meningkat. Menurut teori tentang diskusi terbimbing dengan model model sinektiks, model pertemuan kelas, dan model diskusi kelompok (Djamarah \& Zain, 2006).

Diskusi kelompok adalah gabungan dari model sinektiks dengan model pertemuan kelas. Hanya jumlah peserta relatif kecil. Siswa dikelompokkan menjadi beberapa group sekitar 5 atau 6 orang, sehingga kesempatan individua (masing-masing siswa) untuk berpartisipasi dalam diskusi menjadi lebih banyak.

Dari ketiga model tersebut dapat disimpulkan bahwa dengan diskusi terbimbing siswa dapat mengembangkan kreatifitasnya yang ditunjang rasa dihargai dan menghargai pendapat dari orang lain dalam suatu kelompok. Sehingga tidak hanya dapat meningkatkan hasil belajar secara nyata, tetapi dapat juga meningkatkan interaksi antar siswa dan adanya saling menghargai antar siswa yang akan menunjang iklim pembelajaran yang baik.

\section{B. Pembahasan}

Dari hasil penelitian dapat dianalisis bahwa media diskusi terbimbing dapat digunakan dalam proses belajar mengajar Sejarah Indonesia menggunakan metode diskusi terbimbing yaitu diskusi yang dilaksanakan dengan memberikan pengertian - pengertian oleh guru ketika siswa tidak mengetahui arti atau makna dari suatu kata atau maksud tertentu. Diharapkan metode diskusi terbimbing dapat diterapkan dalam mata pelajaran Sejarah Indonesia dengan pokok bahasan yang lain. Di samping itu juga dapat pula digunakan untuk mata pelajaran yang lain. Memang secara teoritis diskusi terbimbing ini memiliki banyak kelebihan dibandingkan dengan pengajaran yang menggunakan metode lain, seperti telah dipaparkan didepan. Sedangkan dalam praktek dilapangan metode ini sungguh-sungguh dapat mengaktifkan siswa dalam proses belajar mengajar pada siswa kelas X. TSM 1.

Dalam pembelajaran sehari-hari dengan menggunakan metode non diskusi terbimbing siswa yang aktif tidak lebih dari lima orang. Sedangkan menggunakan metode diskusi terbimbing seperti yang telah dieksperimenkan siswa yang aktif lebih dari duapuluh orang. Dengan begitu jelaslah bahwa diskusi terbimbing dapat mengaktifkan siswa-siswa yang biasanya kurang aktif dalam proses belajar mengajar Sejarah Indonesia. Meski begitu pada proses belajar mengajar Sejarah Indonesia dengan menggunakan diskusi terbimbing lebih cocok diterapkan untuk pokok bahasan pokok bahasan tertentu daripada yang lainnya. Pokok bahasan yang dimaksud diatas adalah pokok bahasan yang memerlukan analisis. 


\section{Kesimpulan}

Dari hasil penelitian yang dilaksanakan ada beberapa hal yang perlu disimpulkan dalam penelitian ini. Hasil penelitian menunjukkan bahwa hasil belajar Sejarah Indonesia X mengetahui Materi Pokok Islamisasi dan Silang Budaya di Nusantara Sub Materi Pokok Islam dan Proses Integrasi menunjukkan hasil yang cukup baik sebesar 80,. Hasil yang diperoleh tersebut menunjukkan bahwa hasil dari nilai ketuntasan siswa rata-rata sudah tercapai setelah menggunakan metode diskusi terbimbing.

Untuk meningkatkan pembelajaran dengan metode diskusi ada beberapa komponen yang dapat mendukung pencapaian tujuan pemahaman siswa terhadap mata pelajaran Sejarah Indonesia. Yang terukur dalam hasil belajar Sejarah Indonesia, yaitu penggunaan metode pembelajaran diskusi terbimbing. Dengan alasan memberdayakan potensi siswa dalam menggali pengetahuannya. Metode diskusi terbimbing dapat berguna dan mampu mengantarkan siswa pada tujuan pembelajaran sejarah yang ingin dicapai berdasarkan kurikulum yang berlaku.

Sesuai dengan kurikulum bahwa tujuan Pembelajaran Sejarah Indonesia untuk memahami perkembangan bangsa Indonesia dengan memahami perkembangan kemasyarakatan bangsa Indonesia terutama bangsa Indonesia dengan dunia Internasional. 
Meningkatkan Hasil Pembelajaran Sejarah Indonesia dengan Metode Diskusi

\section{BIBLIOGRAFI}

Djamarah, S. B., \& Zain, A. (2006). Strategi belajar mengajar. Jakarta: Rineka Cipta, 46.

Kemmis, S., \& Taggart, M. (2002). R. 1988. The Action Research Planner.

Slameto, B. (1991). Faktor-faktor yang Mempengaruhinya, cet. II. Jakarta: Rineka Cipta.

Suharsimi, A. (2006). Prosedur penelitian suatu pendekatan praktik. Jakarta: Rineka Cipta. 